\title{
Pedagogický dualizmus teoretického a praktického: historické pozadie a súčasné ilúzie ${ }^{1}$
}

\author{
Emil Višňovskýa,c, Ondrej Kaščák ${ }^{\mathrm{a}, \mathrm{b}}$, Branislav Pupala ${ }^{\mathrm{a}, \mathrm{b}}$ \\ a Slovenská akadémia vied, Ústav výskumu sociálnej komunikácie \\ b Trnavská univerzita v Trnave, Pedagogická fakulta \\ ${ }^{\mathrm{c}}$ Univerzita Komenského v Bratislave, Filozofická fakulta
}

Redakci zasláno 4. 4. 2012 / upravená verze obdržena 4. 6. 2012 / k uveřejnění přijato 8. 6. 2012

\begin{abstract}
Abstrakt: Štúdia sa vracia k tradičnej otázke pedagogiky - ku vztahu teoretického poznania $\mathrm{k}$ praxi, ku vztahu vedy a praxe. K problému pristupuje komplexným teoretickým pohladom, a to tak, že uvedený problém pedagogiky zarad'uje do širších súvislostí vývoja sociohumanitných vied ako takých. Na ich pozadí sú interpretované premeny vztahohov teórie a praxe, ako sa objavovali od antiky cez nástup moderny až po súčasnost'. Vzt’ahové premeny „teoretického“ a „praktického“ sú potom východiskovou osou pre chápanie vývoja pedagogiky v oscilácii jej sebaprezentácie ako teoretickej či praktickej disciplíny. V týchto intenciách je preskúmaný aj dnes populárny koncept učitel'a ako reflektujúceho praktika, ktorý má byt', najmä na poli vzdelávania učitelov, nádejným príkladom, ako definitívne odstránit' neprekonatel'nú priepast', ktorá doposial' stála medzi akademickým poznaním a poznávacími potrebami vynárajúcimi sa pri praktickom výkone výchovy a vzdelávania.
\end{abstract}

Klúčové slová: sociohumanitné vedy, pedagogika, teoretické a praktické poznanie, fronesis, genéza disciplíny, reflektujúci praktik

\section{1 Úvod}

V čase, ked' sú pracoviská sociohumanitných vied na univerzitách či akadémiách rôznymi spôsobmi znovu tlačené do obhajovania svojej legitimity, sa otázka vztahu vedy a praxe opakovane vynára s novou naliehavost'ou a dostáva aj novú príchut'. Pre pedagogiku však akoby nešlo o nič nové, pretože prežívanie napätia medzi teóriou a praxou je akousi až konštitutívnou traumou tejto disciplíny, ktorá ju dokonca istým spôsobom drží bokom od iných sociálnych a humanitných vied. Napriek tomu, že jej definičné pole je celkom dobre vymedzené, pedagogika ako teoretická disciplína vždy

\footnotetext{
1 Štúdia je výstupom riešenia grantového projektu VEGA 1/0224/11 Archeológia neoliberálnej guvernmentality v súčasnej školskej politike a v teórii vzdelávania, a projektu VEGA1/0091/12 Kultúra performativity a akontability v súčasných vlnách vzdelávacích reforiem.
} 
stála na hrane legitimity a vždy čelila silným konfrontáciám s praktickými vykonávatel'mi výchovnej a vzdelávacej praxe. Napokon blízkost' pedagogiky $\mathrm{k}$ vymedzenej oblasti praxis, techné či poiesis vždy tlačila túto disciplínu $\mathrm{k}$ silnejšej konfrontácii s vlastnou prospešnost'ou, a rovnako aj k tomu, aby substituovala svoju teoretickú produkciu spoločenskými objednávkami a politickým fundamentom. Takže v pedagogike aj to, čo sa predkladá ako teoretické, má problém s tým, aby ako teoretické aj naozaj obstálo. História pedagogiky i súčasnost' sa s týmto tlakom i výhradami vyrovnávajú rozličným spôsobom, a hoci ide akousi vlastnou cestou, nepochybne sa na tejto ceste dajú vystopovat’ základné línie premien v chápaní teórie a praxe spoločné pre sociohumanitné poznanie a pre vývoj disciplín $\mathrm{v}$ celom spektre tohto poznania. $\mathrm{V}$ tomto texte preto rekonštruujeme vztah teoretického poznania a praxe na báze širších vývojových súvislostí sociohumanitných vied s cielom lepšie pochopit' situáciu premien pedagogiky a jej spôsobov i pokusov vyrovnat' sa so sebou i s predmetným vztahom. Na tomto pozadí sa napokon snažíme pochopit' aj to, k čomu pedagogika ako fundament „učitel'skej disciplíny" speje dnes, ked' sa obracia k novej forme difúzie teoretického a praktického poznania cez rozšírený a populárny fenomén reflektujúcej praxe.

\section{Filozofický obraz teórie a praxe v sociohumanitných vedách}

$\mathrm{K}$ sociohumanitnému poznaniu a vedám môžeme pristupovat' jednak z hladiska teoretického rozumu (teórie) - čo je vlastne tradičný a stále prevládajúci prístup, ktorý vychádza z klasického antického rozlíšenia l'udskej činnosti na "theoria“ a „praxis", pričom poznanie (noesis) a veda (epistéme) patria do "theoria“ - jednak z hladiska klasickej novovekej idey jednoty vedy, v rámci ktorej sa oblast' sociálneho a humanitného odlišuje od ostatných oblastí vedenia (prírodnej a technickej) len svojím predmetom, avšak všetko ostatné, predovšetkým metódy a ciele, je pre všetky vedy rovnaké. Na základe oboch týchto hladísk sa sociohumanitné vedy nijako zásadne nemôžu vymykat' z tohto celkového rámca a modelujú sa v podstate podla jednotného vedeckého vzoru.

Až vd’aka hermeneutickému obratu v 19. storočí, pripravenému Schleiermacherom a novokantovcami, realizovanému Diltheym a masívnejšie rozvíjanému v 20. storočí $\mathrm{M}$. Weberom, ale aj niektorými d’alšími významnými 
predstavitel'mi rôznych variantov interpretativizmu (A. Schützom, P. Winchom), no najmä interpretatívnemu obratu H.-G. Gadamera (Bohman, Hiley, \& Shusterman, 1991) sa v oblasti sociálneho myslenia a poznania začala udomácňovat' idea, že špecifickost' sa tu netýka iba predmetu, ale aj samých metód skúmania. No aj napriek všetkým týmto metodologickým obratom zostával nedotknutý ciel' - všetky vedy vrátane sociohumanitných sú oblastou teoretického (rozumu) a ich ciel'om je (teoretická) pravda, akokol'vek špecifická svojou historickost'ou, individuálnost'ou, konkrétnostou atd'. Jednoducho ciel'om sociálnych a humanitných vied je takisto smerovat' a dospievat' $\mathrm{k}$ vysvetleniu, resp. pochopeniu svojho predmetu a artikulovat' to v teórii, akokol'vek odlišnej od ostatnej vedeckej (prírodovednej) teórie napríklad v tom, že je nielen explanáciou príčin, ale aj interpretáciou sociálnych a historických udalostí, inštitúcií, noriem či intencií a dôsledkov l'udského konania. Analogicky potom tak ako ostatné vedecké (prírodovedné) poznanie prinajmenšom od čias F. Bacona nie je cielom samo osebe, ale má byt' užitočné a slúžit' praktickým potrebám a životu l'udí, teda nachádzat' svoje uplatnenie a aplikáciu v rôznych oblastiach praxe (materiálno-výrobnej, technologickej a pod.), aj sociálne a humanitné vedecké poznanie má teda byt' podkladom a návodom na formovanie a reformovanie spoločenskej praxe (ekonomickej, politickej atd'.). Základný model štruktúry a fungovania celej vedy zostával v zásade rovnaký, len sociálne a humanitné vedy neustále „zaostávali“ a usilovali sa „dobiehat'“ ostatné vedy, čo sa im nikdy uspokojivo nedarilo, hoci vynašli dostatočne sofistikované apológie i stratégie, ktoré legitímne dokazovali odlišnost' ich predmetu a jemu zodpovedajúcich metód.

Pokial' teda išlo o základné ciele, ktorými boli: 1. teoretické poznanie a 2. jeho aplikácia v praxi, tie zostávali nedotknuté, hoci aj tu mnohí oprávnene poukazovali na d’alšie špecifiká a rozpracúvali dômyselné stratégie, ako dokázat' užitočnost' a praktickost' týchto vied. Až doposial' sa hlavné úsilie filozofov a metodológov sociohumanitných vied i samotných vedcov sústred'ovalo na to, ako sa dopracovat' k tomu najvyššiemu stupňu teoretickosti poznania, t. j. jeho explicitnosti, univerzálnosti, abstraktnosti, diskrétnosti, systematickosti, úplnosti a predikatívnosti, ${ }^{2}$ a následne $\mathrm{k}$ cestám a spôsobom jeho uplatnenia v spoločenskej praxi. Problémy, na ktoré pritom narážali, vyplývali práve zo základnej koncepcie vedy, založenej na tradičnom dualizme teoretického a praktického.

2 Tieto znaky ideálneho typu teórie uvádza Flyvbjerg (2001, s. 38-39) a rekonštruuje ich na základe antickej (prvé tri znaky) a modernej koncepcie (d’alšie štyri znaky). 


\subsection{Teória a prax v antickej koncepcii}

Pôvodný význam termínu „teória“ sa svojimi koreňmi vracia až k Pytagorovi: ten pozoroval, že existujú aj l'udia, čo v živote nehl'adajú ani peniaze a bohatstvo, ani slávu a moc, ale chcú sa len pozerat', pozorovat', čudovat' sa, obdivovat', milovat' krásu a múdrost' bytia. ${ }^{3}$ „Theoros “ bol pôvodne divák na gréckych hrách a festivaloch a jeho činnost'ou bolo práve pozerat' sa, pozorovat'. Pôsobil aj ako posol, vyslanec iného štátu s ciel'om pozorovat' športové a umelecké festivaly. Bola to teda čestná a vznešená postava i pozícia a činnost'. Takáto činnost' nebola ničím podradným, zaznávaným alebo menejcenným či neužitočným, skôr naopak, bolo to niečo vyššie, vznešené, dokonca božské. ${ }^{4}$ Takýto „pozorovatel“" bol oslobodený od zhonu a zháňania, aj od pôžitkov, za ktorými sa ženie väčšina l'udí, od starostí a vzruchov, a tým aj od dočasnosti - bol to pokus človeka prekonat' svoju smrtel'nost' smerom $\mathrm{k}$ večnosti. Bios theoretikos teda nebol bežný l'udský život - teoretikov v živote viedla a vedie snaha pochopit', zvedavost', túžba „nemat' prázdnu hlavu“, ale aj údiv a podobne. ${ }^{5}$

Tradícia, v ktorej sa zrodilo a uchovávalo dominantné rozlišovanie a používanie termínov „teoretický“ a „praktický“ - hoci má platónske korene je nepochybne aristotelovská. Obaja, Platón i Aristoteles, najprv zakladali toto rozlíšenie ani nie tak na dvoch protikladných formách či sférach l'udskej činnosti, ako na spôsoboch (formách) l'udského života. U Platóna (1990, s. 68 $\mathrm{A}-\mathrm{C}$ ) išlo rozlišovanie foriem života $\mathrm{v}$ línii duša/telo: kontrast medzi nimi je takisto zásadný - milovníci duše žijú iný život než milovníci tela; tí druhí sa orientujú na telesné pôžitky, ako sú sláva, moc, peniaze i niektoré d'alšie. Už tu vidiet', že ciele oboch foriem života sú odlišné: praktické dobro je aj pôžitok (u Platóna, nie však u Aristotela) a zároveň aj úžitok, čest' atd'., kým teoretické dobro je (večná) pravda. Teoretik žije pre jedno (pravda, poznanie,

3 „Život prirovnával k národnej slávnosti. Pretože ako na ňu prichádzajú jedni ako pretekári, druhí za obchodom, tretí najlepší ako diváci, tak sa v živote rodia jedni, l'udia otrockí, ako lovci slávy a bohatstva a druhí, filozofi, ako lovci pravdy“ (Díogenés Laertios, 1995, VIII, s. 8).

O tom svedčí aj spoločný koreň gréckych slov theos-theoros-theatros.

5 „Čistá teória“ je potom produkt platónskej filozofie a prekonanie platonizmu je úloha, ktorú dejiny filozofie zatial' nevyriešili. Odmietanie platónskej „čistej teórie“ však nemusí znamenat’ odmietanie teórie vôbec. Tým „svorníkom“ medzi teóriou a praxou, ktorý má skutočný zmysel, by mohla byt' sokratovská antropologická téma „dobrého života“. „Vediet", čo je dobrý život, je jedna vec - „teoretická“. „Mat"“ dobrý život, je druhá vec - praktická. Je zrejmé, že skutočne „žit’ dobrý život“ je vec aj teoretická, aj praktická, je to vec „umenia žit", kde už rozlišovanie teoretického a praktického stráca zmysel. Lebo zmyslom samým (aj života, aj filozofie) je „žit’ dobrý život“, teda - „umenie žit“" samo. 
pochopenie), praktik pre druhé (pôžitok, úžitok). Aristoteles (1979, s. 1095 b) rozlišoval v etickom kontexte „tri hlavné formy života človeka“: 1. „požívačný život“ (o ktorom sa vyjadril, že je skôr zvierací ako l'udský), 2. „život v službe štátu“ a 3. „život oddaný filozofii“; v politickom kontexte rozlišoval dve formy života: 1. „politický a praktický život“ a 2. „teoretický, kontemplatívny“ život (Aristoteles, 1988, s. 1324 a). ${ }^{6} \mathrm{~V}$ Politike teda Aristoteles formuloval rozdiel medzi praktickým a teoretickým životom viac z hladiska spoločenského než individuálneho: prvý sa aktívne zúčastňuje na živote obce, druhý je od neho skôr oddelený, izolovaný. Spojením oboch rozlíšení - platónskeho i aristotelovského - sa neskôr zafixovalo toto chápanie (a musíme povedat', že konfúzne): telesný, vonkajší a občiansky (spoločenský) život je „praktický“, kým duchovný, vnútorný a „súkromný“ život je „teoretický“.

Aristoteles (1988, s. 1325 b) však zaviedol do filozofického slovníka aj termín „prax“ v zmysle určitej podoby l'udskej činnosti: „praxis“ je l'udská činnost', konanie vo všeobecnosti s výnimkou: 1 . fyziologických činností tela, 2. čisto intelektuálnych činností, ako sú myslenie a uvažovanie. No Aristoteles je aj v tomto nejednoznačný: praxis je uňho takisto život, životná činnost' aj v najširšom biologickom zmysle, ba niekedy hovorí aj o myslení ako o praktickej činnosti.

V rámci koncepcie ludskej činnosti Aristoteles odlišuje praxis od „poiesis“ (tvorenie, vytváranie, výroba) podla toho, že prvé má ciel' samo v sebe ciel'om je sama činnost' - kým druhé má ciel' mimo seba, v produkte. ${ }^{7}$ Ciel' prvej sa plní už vtedy, ked' sa vykonáva, ciel' druhej sa naplní, až ked' sa skončí. Niektoré činnosti preto nechceme prestat' vykonávat', iné zasa nechceme ani začat' vykonávat'. Niektoré ciele nedosiahneme bez niektorých činností (práca), kým niektoré činnosti vykonávame najradšej pre ne samotné. Podl'a Aristotela (1988, s. 1254 a) život je činnost', nie výroba, preto ak sa zo života stane prostriedok na niečo iné, dochádza k zmene účelu a zmyslu

6 Contemplatio je však neskorší latinský termín pre pozeranie sa, pozorovanie, uvažovanie, rozjímanie; pôvodne mal tiež náboženský význam: templum je posvätné miesto, chrám, svätyňa.

7 Túto antickú koncepciu môžeme konceptuálne usporiadat' takto:

\begin{tabular}{ll}
\hline Oblast' života (činnosti): & Oblast' poznania (znalosti, zdatnosti): \\
\hline theoria & nous, sofia, epistéme \\
praxis & fronesis \\
poiesis & techné \\
\hline
\end{tabular}


činnosti. ${ }^{8}$ Pre Aristotela je však praxou najmä tá činnost', ktorá je politická alebo etická (Lobkowicz, 1967, s. 11), aj to len činnost' slobodného človeka. Odtial' pochádza užší význam termínu „prax“ - v zmysle l'udského života alebo l'udských záležitostí, l'udskej činnosti ako rozumnej a ciel'avedomej, účelovej činnosti, lebo taký je jej subjekt. Za takouto praxou je výkon l'udskej mysle či rozumu - vedomé rozhodnutie alebo vol'ba na základe žiadosti a ciel'avedomej úvahy (proairesis).

Rozdiel, ktorý Aristoteles inauguroval, je tento: prax je nielen konanie, ale je to rozumné konanie, t.j. konanie, ktoré má svoju vlastnú racionalitu, a teda aj vlastné poznanie - predmetom praktického rozumu, t.j. rozumu zameraného na konanie, je praktické dobro a úžitok, nie poznanie samo. Predmetom teoretického rozumu zasa nie je prax, ale pravda a poznanie samo - teda teória a prax, poznanie a dobro sú dve veci; teória o praxi (teória praxe) nie je podla neho možná; teória sa nezaoberá praxou, ale má iný predmet, tak ako prax sa nezaoberá teóriou, ale svojím predmetom - dobrom a úžitkom, lebo aj keby sme skúmali prax a zaoberali sa ňou, naším praktickým cielom nie je vediet', čo je odvaha, ale byt' odvážnym; nie, čo je zdravie, ale byt' zdravým atd'. „Eupraxia“ je dobré konanie a z praktického hl'adiska má preň význam len také poznanie, ktoré k tomu prispieva - a to je „praktické poznanie“. Podla Aristotela praktické veci neskúmame preto, aby sme ich poznali, aby sme o nich vedeli a definovali ich, ale aby sme ich konali a nadobudli praktické cnosti.

Analogicky Aristoteles rozlišuje aj poznávanie a uvažovanie - deliberáciu: predmetom poznávania sú nemenné, večné podstaty, kým predmetom uvažovania je to, čo budem konat'. Teoretickou vedou je teda napr. fyzika, kým etika a politika sú úplne iné, pretože 1. oblast' praxe je oblast' l'udského života a tá má do činenia s jednotlivými a premenlivými vecami, 2 . cielom etiky a politiky je viest' l'udské konanie. V tom sú etika a politika „praktické vedy“, a preto nemôžu byt' „pravým“ poznaním v zmysle poznania večných podstát, aké dosahuje fyzika. Oblast' praxe, l'udského konania je jednoducho podla Aristotela (1979, s. 1137 b) iného druhu a povahy. Tu nemôžeme očakávat' takú striktnost' a presnost' ako v oblasti vedy a fyziky. V tejto aristotelovskej koncepcii je obsiahnutá myšlienka, že v oblasti etiky a politiky ako praktických

$8 \quad \mathrm{~V}$ modernej dobe je to fenomén inštrumentalizácie života. Napríklad šport sa v modernej spoločnosti z činností, ktoré tradične mali ciel' samy v sebe, stal prostriedkom pre niečo iné (body, postavenie v tabul'ke a odmeny zaň sú ciel’om, a nie športový výkon alebo sama hra). 
záležitostiach nemôžeme dosiahnut' takú vedeckost', resp. vedeckost' v takej istej podobe ako v oblasti fyziky. Je teda nemúdre sa o to usilovat'.

Aristotelova dištinkcia medzi teoretickým a praktickým sa teda spája $\mathrm{s}$ jeho poňatím rozumu a rozumnosti - fronesis ${ }^{9}$. Význam tohto slova sa v gréckom jazyku i gréckej filozofii menil. Ako ukazujú analýzy špecialistov, u predsokratikov mal pojem fronesis pôvodne praktický a etický význam (u sofistov dokonca ako druh „vypočítavej rozumnosti“), avšak Sokrates mu dal teoretický odtieň a u Platóna, ktorý podriadil prax teórii, sa fronesis celkom vztahuje na kontempláciu a zostáva $\mathrm{v}$ hraniciach teoretického rozumu, resp. múdrosti (Aubenque, 2003, s. 18, 21). Z tohto poňatia pôvodne vyšiel aj Aristoteles (1972, XIII, s. 4,), ktorý ešte v Metafyzike hovorí o fronesis ako o type nemenného vedenia o nemennom bytí. Až neskôr Aristoteles $\mathrm{v}$ kontexte svojich úvah o etike dospieva $\mathrm{k}$ potrebe odlísit' fronesis od tradičných príbuzných pojmov ako nús, epistéme a sofia. Vo svojich etických spisoch, najmä v Etike Nikomachovej už Aristoteles koncipuje fronesis inak: nie ako vedenie či vedu, ba dokonca ani ako múdrost', ale ako intelektuálnu (dianoetickú) cnost', resp. ako praktickú zdatnost', ktorá sa týka náhodilého, premenlivého, konkrétnych okolností a konania jednotlivca (Aristoteles, 1979, s. 1140 a - 1145 a). Fronesis je podl'a Aristotela „rozumnost"“ na rozdiel od „múdrosti“ (sofia) a stáva sa praktickou rozumovou cnost’ou, ktorej „podstatou je konanie“ (1979, s. 1141 b). Teda tam, kde ide o konanie (prax), potrebujeme iné cnosti a zdatnosti, aby sme dosiahli svoje ciele, ktorými sú rôzne podoby blaženosti, „vlastného dobra“, celkové „usporiadanie vlastných životných pomerov" (1979, s. 1142 a).

Aristoteles touto dištinkciou múdrosti a rozumnosti, ktorá je analógiou dištinkcie teoretického a praktického rozumu, napokon nemieni ani nadrad'ovanie jedného druhému, ani ich roztržku, len poukazuje na potrebu ich odlíšenia a na špecifickost', pokial' ide o ich predmety a ciele (1979, s. 1144 a - 1145 a). Musíme takisto vidiet', že táto Aristotelova dištinkcia zostáva v hraniciach rozumu či intelektu a neprekračuje ich smerom do praxe ako reálneho konania - ide vlastne o dve odlišné orientácie toho istého l'udského rozumu vzhl'adom na ich predmet, ciel' a funkciu: jedna „čast'“ tohto rozumu (intelektu) sa orientuje na poznanie (epistéme) v zmysle pochopenia podstaty vecí a tú Aristoteles nazýva „múdrost" (sofia) ako „najdokonalejšiu formu poznania“ (1979, s. 1141 a), druhá sa orientuje na konanie (praxis)

9 Fronesis - rozum, bystrost', myšlienka, dôvera, sebavedomie, pýcha, vernost', poznanie. Fronimos - rozumný, múdry, rozvážny (Prach, 1998, s. 560). 
v zmysle dosahovania blaženosti v živote a usporiadania si životných pomerov, a tú Aristoteles nazýva „rozumnost“" (fronesis). Zároveň však Aristoteles jasne hovorí, že reálne konanie (prax) sa neriadi a nemá riadit' múdrost'ou (sofia) tak ako u Sokrata a Platóna, ale práve rozumnostou (fronesis), teda že táto „praktická“ čast' rozumu je vhodnejšia či lepšie prispôsobená konaniu.

Aristotelovo dedičstvo vyvolalo kontroverzie už u jeho bezprostredných nasledovníkov (Aubenque, 2003, s. 21-23). Jednu školu reprezentoval Teofrastos, podl'a ktorého sa l'udský duch (mysel') má orientovat' na poznanie a múdrost' a človek má žit' skôr kontemplatívny život (život ducha, vita contemplativa), v rámci ktorého je „praktická rozumnost'“ len niečo podradné, pretože obsahuje „druhoradé poznanie“. To je pohl'ad na rozumnost' a konanie zo stanoviska poznania a teórie. Druhú školu reprezentoval Dikaiarchos, ktorý bol rozhodným zástancom orientácie ducha (mysle) na konanie, a teda smerom $\mathrm{k}$ prakticky činnému životu (aktívny život, vita activa). Tento druhý pohlad smeruje $\mathrm{k}$ niektorej z týchto alternatív: 1 . nahradenie múdrosti rozumnost'ou (fronesis namiesto sofia), 2. podriadenie teórie praxi, 3. znovuzjednotenie teórie a praxe a teoretického a praktického rozumu. Tieto tendencie sa presadili neskôr v modernej dobe. Krok k prekonaniu protikladu múdrosti a rozumnosti však urobili už stoici, ktorých chápanie fronesis znovu ako vedenia o tom, čo máme konat', aby sme dosiahli dobro a vyhli sa zlu (Aubenque, 2003, s. 43, 215), nás vedie $\mathrm{k}$ tomu, že pojem „praktická múdrost" - ako niektorí navrhujú chápat' fronesis - nemusí byt' contradictio in subjecto. Dokonca práve v tejto, skôr stoickej než pôvodne aristotelovskej podobe, sa fronesisako „praktická múdrost"“ vracia dnes do filozofie sociálnohumanitných vied (Flyvbjerg, 2001, s. 2).

\subsection{Teória a prax v modernej koncepcii}

$\mathrm{V}$ antike diferencia medzi teoretickým a praktickým ešte neznamenala diferenciu medzi abstraktným a konkrétnym, mysleným a žitým, duchovným a materiálnym, vnútorným a vonkajším (Lobkowicz, 1967, s. 35), hoci pôvodný Platónov koncept, idúci v línii duša/telo, utváral na to predpoklady. Teória sama však bola ponímaná ako forma života, akokolvek odlišná od iných foriem života patriacich do „praxe“. Praktické ešte nenadobudlo význam „reálneho" oproti teoretickému ako abstraktnému či dokonca čisto fiktívnemu, existujúcemu len v ríši ideí, úvah, zámerov a pod., pretože „teoretické“ nestálo v opozícii voči „praktickému“ na spôsob dualizmu myslenia a konania; „teoretické“ bolo len jedným druhom poznania (epistéme) a múdrosti (sofia) 
v rámci celkového života ducha (vita contemplativa). „Slovom to, čo dnes nazývame ,aplikovaná veda', bolo Grékom takmer neznáme. Poznanie bolo bud' teoretickým v prísnom zmysle slova a potom sa týkalo univerzálneho a večného a nemalo nijaké aplikácie v oblasti ,konania' a ,vytvárania', alebo bolo aplikovatel'né $\mathrm{v}$,konaní a ,vytváraní, a teda v nijakom relevantnom zmysle nebolo pre grécke myslenie teoretickým. Vlastne, ak bolo poznanie aplikovatel'né na ,konanie' a ,vytváranie', nebolo skutočne vedecké a v každom prípade bolo bližšie každodennej skúsenosti než,kontemplácii'... Produktívne poznanie pre Grékov určite nebolo ,aplikovatel'né teoretické myslenie““ (Lobkowicz, 1967, s. 42-43).

K takémuto obratu došlo až v modernej dobe. Tento obrat zároveň znamenal reorientáciu všetkého teoretického na prax, t. j. zrušenie zásadného rozdielu medzi teoretickým a praktickým poznaním a zásadnú požiadavku uplatňovat' (aplikovat', využit') všetko poznanie v praxi, teda „čisté poznanie“ alebo „čistá veda“ v zmysle platónskeho nazerania večných podstát strácali svoje opodstatnenie. Zároveň s takýmto stotožnením toho, čo v antike bolo „vyšším“ druhom poznania, teda teóriou, s prakticky orientovanou vedou (scientia) sa aristotelovské „praktické poznanie“, orientované na dočasné a premenlivé predmety a na blaženost' (dobro, štastie) človeka, dostalo do postavenia „druhoradého“ poznania, ktoré - ak ho chcelo prekonat' - sa muselo začat' „dvíhat'“ tiež na úroveň teórie (epistéme) či vedy (scientia).

Modernita teda začala požadovat' dve veci naraz, ktoré antika odlišovala a brala samostatne: 1 . dokonalú teóriu v zmysle poznania podstát, 2. dokonalú prax v zmysle aplikácie dokonalej teórie. Len sama čistá teória stratila zmysel a hodnotu a s ňou aj čistý kontemplatívny život. Analogicky sama prax, nefundovaná takouto teóriou, začala byt' pokladaná za niečo nižšie, podradné. Ideálom sa stala „jednota teórie a praxe“, ktorá požadovala: 1. uplatnenie každej teórie v praxi (bud' bezprostredne, alebo principiálne); 2. založenie každej praxe na teórii (bud' bezprostredne, alebo principiálne). Bolo to fakticky nové poňatie teórie ako vedeckého poznania, ktoré má - pokial' možno čo najbezprostrednejšie - slúžit' tomu, čo antická tradícia nepožadovala od teórie, ale od aristotelovskej fronesis - dokonca od teórie sa teraz začalo požadovat', aby slúžila nielen praxi, ale aj poiesis, teda tvoreniu a produkcii, čo Gréci požadovali zasa od techné. ${ }^{10}$ Teória ako veda zaujala v modernite

10 Techné - remeslo, umenie, náuka, zamestnanie, umelecké dielo, obratnost', skúsenost', prostriedok, spôsob, zdatnost', rozvážnost', úskok (Prach, 1998, s. 521). Ideu spojenia modernej vedy s techné kritizoval napr. M. Heidegger. 
miesto, resp. funkcie fronesis aj techné bez toho, aby teória sama prestávala byt' „nazeraním prvých podstát“. Avšak teória, ktorá v modernej dobe neslúži praxi a výrobe ako praktické poznanie a technológia, stáva sa abstraktnou, odt'ažitou, neužitočnou a zbytočnou. Ak u Platóna bolo všetko poznanie orientované na seba samo a u Aristotela čast' poznania bola orientovaná na konanie, tak teraz už malo byt' všetko poznanie bez výnimky orientované na konanie, prax.

Najdôležitejším dôsledkom modernej vedeckej revolúcie bolo prevrátenie hierarchie medzi vita contemplativa a vita activa (Arendt, 1998, s. 289). Hoci sa tento „pragmatický“ či „protopragmatický“ obrat vedy - ktorý sa napokon stal trvalým impulzom pre modernitu - k tomu, aby sa aj ona sama posudzovala podla „plodov a diel“, ktoré prináša, spája najmä s menom Francisa Bacona, prevážila ho na dlhý čas Descartova antiaristotelovská koncepcia. Podla nej je praktické poznanie len pravdepodobnostné a musí ustúpit' istému teoretickému poznaniu. Descartes, Galilei i Newton to chápali ešte platónsky: veda má ciel' sama v sebe a nemusí byt' overovaná a potvrdzovaná praktickým úžitkom. Napríklad hodinky neboli vynájdené na praktické, ale teoretické účely merania vo vedeckom experimente a až následne sa ukázali ich praktické významy a dôsledky, aj to iba náhodne. Je to teda paradoxné: keby sme sa riadili iba praktickým ciel'mi, nikdy by neboli vznikli také prakticky užitočné vynálezy, aké máme, lebo k tým viedli práve teoretické záujmy. Na druhej strane sa však ukázalo, že samo poznanie a pravdu už nie je možné dosiahnut' iba pasívne, kontempláciou, ale že treba byt' činní, aktívne experimentovat' (Arendt, 1998, s. 290). Veda sa stala „praktickou“ v tej miere, v akej sa stávala empirickou - namiesto kontemplácie nastúpilo vedecké myslenie a teória prestala byt’ kontemplatívnou. Myslenie sa stalo slúžkou konania tak, ako predtým bolo slúžkou kontemplácie a sama kontemplácia sa stala zmysluprázdnou (Arendt, 1998, s. 291-292). V rámci vita activa sa vítazne presadila práca ako vytváranie a produkovanie (Arendt, 1998, s. 294).

Pre sociohumanitné vedy a ich filozofiu z toho vyplynula táto situácia: 1. zachovat' si svoju orientáciu na prax, ale 2. pozdvihnút' sa z čisto „praktického poznania“ na „teoretické poznanie“, ktoré je dokonalejšie a ktoré má odteraz rovnako praktické poslanie a funkcie. Výsledkom bolo, že tento model celkom dobre nefungoval - tým, že sa sociohumanitné vedy usilovali „dvíhat" na teoretickú úroveň, stávali sa abstraktnejšími a strácali svoju praktickost'. Tento 
proces môžeme nazvat' aj „teoretizáciou“ sociohumanitných vied v zmysle ich zvedečtenia, scientizácie, t. j. nahradenia čisto náhodného, empirického alebo „situačného“ poznania skutočne vedeckým, teda poznaním zákonitostí podla vzoru prírodných vied či vedy „vôbec“. Túto teoretickú či vedeckú ambíciu sociohumanitných vied jasne vidiet' už na Hobbesovi, Spinozovi a Humovi, ktorý sám chcel byt' „Newtonom morálnych vied“, ako aj na všetkých d’alších vrátane Marxa, J. S. Milla atd'. Udomácnila sa teda karteziánska idea možnosti „teórie praxe“, t. j. teoretického poňatia a poznania praktických ludských záležitostí. Takáto teória v sociohumanitných vedách podla Grékov nielenže nebola potrebná, ale nebola ani možná.

To, čo v antickej tradícii patrilo do oblasti „praktického“ (rozumu, poznania, myslenia), t. j. oblast' politiky a etiky (konania, praxis), ale aj hospodárskeho života (tvorenia, poiesis), sa $\mathrm{v}$ modernej dobe stalo oblast'ou (polom, predmetom) sociohumanitných vied. Je tu nepochybná súvislost' medzi sférou praktického $\mathrm{v}$ antike a sférou sociohumanitného $\mathrm{v}$ modernite, lenže $\mathrm{s}$ tým rozdielom, že $\mathrm{v}$ modernite sa aj praktické podriad'uje teórii (vede) a teoretické (vedecké) má slúžit' praxi - teda tam, kde antika vyčlenila praktické bud' ako odlišnú oblast' rozumu, alebo dokonca ako odlišnú oblast' konania a života, modernita vt'ahuje praktické pod teoretické/vedecké vo viacerých významoch: 1 . teoretické má slúžit' praktickému a samo teoretické má byt' prakticky užitočné; 2 . teoretické má skúmat’ samo praktické ako svoj predmet a vytvorit' „teóriu praxe“ bez toho, aby prestalo byt' teoretickým/ vedeckým, čo predtým nebolo možné (hoci takáto idea je už u T. Akvinského); 3. praktické má byt' previerkou teoretického.

Modernita tak nastolila problém: ak máme skúmat' prax teoreticky a ak je to možné, má to byt' teória, ktorá bude svojou povahou rovnaká ako teória prírodovedy? Problém komplikuje požiadavka, že aj teória prírodovedy má byt' v modernite „praktická", t. j. využitel'ná pre l'udské ciele. No v sociohumanitných vedách ide o niečo iné - o otázku „teórie praxe“, t. j. či je možné vedecky uchopit' praktické l'udské záležitosti rovnako, ako to robí prírodoveda? Za touto otázkou je moderná idea jednoty vedy a snaha dat' aj l'udskému konaniu poznanie v zmysle odhalenia nevyhnutného („železného“) zákona tohto konania. U Kanta sa problém presunul do roviny normativity - k stanoveniu noriem pre konanie, ktoré treba urobit' tiež na báze vedeckej teórie. 


\section{Sociálnovedné štrukturácie vzt’ahu teórie a praxe}

V súčasnosti možno evidovat' mnohé varianty riešenia problému teórie a praxe v sociálnych vedách. Súčasný dánsky sociálny vedec B. Flyvbjerg (2001) prišiel napr. s koncepciou sociálnej vedy dôsledne budujúcej na aristotelovskej fronesis. ${ }^{11}$ Podl'a neho fronesis je obsiahnutá v sociálnej praxi (praktikách), „a preto pokusy redukovat' sociálnu vedu a teóriu bud' na epistéme, alebo na techné, prípadne obsiahnut' ich týmito pojmami, je chybné" (Flyvbjerg, 2001, s. 2). Sociálne vedy však zabudli na Aristotelovu fronesis a kládli si nesplnitel'né ciele: imitovat' svojou teóriou prírodovedné teórie a sútažit' s nimi v epistemických kvalitách. Úloha sociálnych vied je iná a spočíva práve vo fronesis - v analýze hodnôt a záujmov a v poskytovaní východísk pre spoločenský rozvoj (Flyvbjerg, 2001, s. 3). Za jednu z hlavných príčin tohto vývoja považuje Flyvbjerg to, že ani klasický aristotelovský pojem fronesis, ani jeho súčasné verzie, napríklad gadamerovská, nezahrnuli do seba reflexiu moci a konfliktu ako konštitutívnych sociálnych fenoménov. Práve takúto koncepciu fronesis si dáva za ciel' rozpracovat', čím chce

obnovit' sociálne vedy v ich klasickom postavení ako praktickej intelektuálnej aktivity zameranej na vyjasňovanie problémov, rizík a možností, ktorým čelia ludia i spoločnosti, a na príspevok k spoločenskej a politickej praxi. (Flyvbjerg, 2001, s. 4)

Imitácia prírodných a technických vied na báze kognitivizmu a naturalizmu zaviedla hlavný prúd sociálnych vied do slepej uličky. Preto je potrebná ich reorientácia založená práve na koncepcii fronesis. Tento projekt reformy sociálnych vied má smerovat' k vytvoreniu "fronetickej sociálnej vedy“ (Flyvbjerg, 2001, s. 4-5).

Flyvbjergov pokus je jeden z mnohých pokusov o vymanenie sa z dualizmu teórie a praxe, s ktorým sociálne vedy zápolia už od 60-tych rokov 20. storočia. Typickou bola kontroverzia J. Habermasa a N. Luhmana (1971) polemizujúca o vhodnosti systémovej teórie spoločnosti ako jediného vedeckého modusu racionalizácie sociálneho konania. Obaja sa však v zásade zhodli na skutočnosti, že vedecké poznanie je nadradené iným formám sociálneho poznania a konania. $V$ sociálnych vedách tak predsa len pretrváva predstava o najvyššej spoločenskej autorite teórie. Feyerabend (1980) to označuje ako

11 Aristotelovskú ideu fronesis ako relevantnú pre filozofiu sociohumanitných vied uviedol ako jeden z prvých H.-G. Gadamer (2010) vo svojom opus magnum. 
„idealistický“ koncept vztahu teórie a praxe a odlíšil ho od konceptu „naturalistického", na základe ktorého je vedecké poznanie určované potrebami praxe. V idealistickom podaní dosahuje svet praxe využívaním teoretického poznania vyššiu úroveň racionálnosti. Vztah teórie a praxe sa tak chápe ako deduktívny proces zhora nadol, proces zvedečtovania praxe. Tento model nadobúdal v sociálnych vedách od 60-tych rokov 20. storočia na sile.

Vel'ké očakávania sa spájajú so schopnostou sociálnovedného poznania riadit' a plánovat' sociálny a politický rozvoj. Takmer všetky spoločenské polia praxe, ako politika, hospodárstvo, vzdelávacie inštitúcie alebo sociálna práca sa odvtedy domáhali rozvoja svojho profesionálneho konania na základe vedeckého poznania. $\mathrm{V}$ tomto zmysle bol vedecko-centrický model spoločenskej racionalizácie úspešný. (Altrichter, Kannonier-Finster, \& Ziegler, 2005, s. 26)

Ako uvádzajú Beck a Bonß (1989), okolo postulátu vyššej autority teórie vo vzt’ahu k sociálnej praxi sa odvíjajú tri základné druhy argumentácie:

Diferencujúca argumentácia vidí problém najmä v aktuálnej vedeckej produkcii a s cielom produkovania lepšej teórie pre prax požaduje produkciu vedeckého poznania cez kvalitnejší a masívnejší výskum. Zároveň treba podrobit' výskumu aj aktérov praktického pola, aby sa zistila podoba ich recepcie vedeckého poznania a podmienky adekvátnej recepcie.

Negujúca argumentácia vníma nefungujúce aspekty transferu teórie do praxe, pričom problém nevidí $\mathrm{v}$ nekvalite vedeckej produkcie, ale $\mathrm{v}$ jej neadekvátnych cieloch a nasmerovaní. Postuluje sa tak zmena orientácie vedeckej produkcie na iné oblasti a ciele.

Korigujúca argumentácia chápe problém vztahu teórie a praxe ako fundamentálny. Hovorí o príkrom rozpore medzi racionalitou teórie a praxe a o nemožnosti priameho deduktívneho využívania vedeckých poznatkov v praxi. Hendikep sa vníma najmä na strane praxe, ktorá trpí deficitom racionality, ktorá znemožňuje teoretický transfer. (Beck \& Bonß, 1989, s. 25)

Beck a Bonß (1989) na základe analýzy týchto troch typov argumentácií dospievajú k štvrtému, skôr induktívne ladenému argumentu. Zriekajú sa hierarchického vzt'ahu teórie a praxe a chápu ich ako dve kvalitatívne odlišné formy vedenia. Prax je podla nich relatívne autonómnym pol’om nezávislým od teórie. Sú to dve polia konania a poznania, jedno toho vedeckého, druhé toho praktického. Zároveň hovoria o štrukturálnej diferencii medzi teoretickým a praktickým vedením. Produkcia vedeckého poznania je odbremenená od 
konania ako určujúceho kontextu pre produkciu poznania, zatial' čo praktické vedenie je pod tlakom konat' ako určujúcim kontextom praxe.

\section{Rozporuplnost' teórie a praxe ako fundament pedagogiky}

V pedagogike možno sledovat' prevrátenú podobu tradičnej sociálnovednej hierarchie teórie a praxe. Koncept praxe sa tu odjakživa javí ako určujúci. „Ak chápeme prax ako výchovnú skutočnost', potom neexistuje taký teoretický prístup v pedagogike, ktorý by sa na ňu nevztahoval“ (Tschamler, 1996, s. 107). Pedagogiku možno chápat' ako „fronetickú sociálnu vedu“, nie však vo Flyvbjergovom, ale skôr v klasickom aristotelovskom zmysle slova. Vo svojej súčasnej podobe totiž v našom kultúrnom kontexte produkuje najmä „rozumnost', ktorej „podstatou je konanie“, teda „praxis“-ak by sme mali vrátit” $\mathrm{k}$ Aristotelovi. Modernizačné tlaky zároveň ovplyvnili pedagogiku, podobne ako iné konkurenčné sociohumanitné vedy tým smerom, že dochádzalo k snahe pozdvihnút' pedagogiku z úrovne praktického poznania na úroveň jeho teoretizácie. Tento proces bol osudom pedagogiky celého 20. storočia, $\mathrm{v}$ našich podmienkach naštartovaný $\mathrm{v}$ dvoch vlnách začiatku a poslednej dekády 20. storočia. Exemplárnym príkladom takejto umelej „teoretizácie“ je vývoj všeobecnej didaktiky, ako aj odborových didaktík, ktorý sa dial tak, že vytváral kváziteoretické poznanie na báze klasifikačných deskripcií zjavnej reality, inštalujúcimi akademický slovník na triviálne pedagogické evidencie (Kaščák \& Pupala, 2007). Išlo sčasti aj o dôsledok univerzitnej akademizácie „fronetických vied“, tak ako v našich podmienkach prebiehala v prípade pedagogiky pri rozširovaní vysokoškolského vzdelávania učitelov, ale takisto napr. aj v Nemecku (v prípade študijného odboru veda o výchove Erziehungswissenschaft) a celom centrálnom európskom regióne v druhej polovici 20. storočia.

Modernistický pohyb teoretizácie praktického viedol v prípade pedagogiky (už od jej vzniku) ku kantovskému riešeniu - k produkovaniu normativity. Teoretizácia praktického tak má viest' $\mathrm{k}$ tvorbe noriem pedagogického konania. Pedagogika je vo svojom jadre normatívnou pedagogikou. Táto identita sa však periodicky stáva terčom vedeckej kritiky. Ako uvádza Tschamler (1996, s. 94), vo vnímaní pedagogiky ako vedy je centrálnym problémom vztah teórie a praxe, ktorý vyjadrujú tieto dve otázky: 
1. Má teória deskriptívne chápat' a evidovat' pedagogickú prax? Alebo/a:

2. Má teória normovat' výchovné procesy?

Spor o vedeckost' pedagogiky je teda sporom o jej deskriptívnost' a normatívnost'. Lenzen (1996, s. 82) uvádza, že ak sledujeme historický vývoj systematickej pedagogiky, tak „sa sporný vzt’ah ,teórie a praxe ukazuje ako trvalý zdroj generovania všetkých tých kríz, ktoré sprevádzali pedagogiku tak ako žiadnu inú disciplínu“. Zároveň uvádza, že toto vedomie rozporuplnosti tvorí jednotu identity pedagogiky, pričom si pedagogická komunita uvedomuje, že práve táto nejednotnost' odlišuje pedagogiku od iných disciplín a robí ju unikátnou.

Normatívne nastavenie vztahu teórie a praxe vyplýva z genézy pedagogiky ako samostatnej disciplíny. Jej pôvodné vyčlenenie z filozofickej axiológie v podobe filozofickej pedagogiky o jej normatívnom základe vypovedá mnohé. Normatívne ju koncipuje aj prvý systematik pedagogiky J. F. Herbart. Pedagogika je tak od svojho vzniku "svetonázorovou pedagogikou“, operujúcou „S metafyzickými istotami“ (Schäfer, 2007, s. 138). Zároveň sa $\mathrm{v}$ časoch spoločenských a politických zmien stáva zdrojom mnohých nádejí a nositel'om spoločenských misií (vychovat' „nového“ človeka). Andresen (2007, s. 123) uvádza, že takéto idealistické (niekedy až utopické) nastavenie pedagogiky permanentne posilňuje $\mathrm{v}$ disciplíne intenzívne prítomný alternativizmus, iniciovaný reformno-pedagogickým hnutím konca 19. storočia, ktorého cielom bolo skôr výchovné utváranie „lepšieho“ človeka než budovanie akademického charakteru disciplíny. Tieto normatívne požiadavky zostávajú nenaplnené (alebo len sčasti naplnené) a pedagogika si v rôznorodých cykloch uvedomuje „nedostatok realistického odhadnutia svojich možností“ (Andresen, 2007, s. 122), čo „rýchlo vedie k štrukturálnemu pretaženiu“" (Rieger-Ladich, 2007, s. 167).

Normatívne ladenie sa tak stáva predmetom permanentnej kritiky aj v rámci samotnej pedagogickej vedeckej komunity. Najčastejšie zaznieva z tábora obrancov vedeckej, explanatívnej pedagogiky.

Pritom majú mnohí predstavu, že zaoberanie sa normatívnou stránkou výchovy a vzdelávania postačuje, že v prvom rade ide o to, chciet’ niečo špecifické (spravidla niečo dobré) pre ludstvo, spoločnost', blížnych a že úlohou štúdia je ukazovat' cesty, ako sa dá toto dobro dosiahnut'. Prosím, preverte si zretel'ne, či pestujete takéto očakávanie! Ked' sa ho nechcete vzdat', zrieknite sa štúdia vedy o výchove. Dobrí l'udia s pomáhajúcim syndrómom môžu poskytnút' cenné služby na fare, 
v Amnesty International alebo u anonymných alkoholikov, vedecké vysokoškolské štúdium na to nepotrebujú. (Lenzen, 1999, s. 26)

V klasickejšom kabáte vyjadruje obdobné A. Fischer, reagujúc na reformnopedagogické vplyvy na pedagogiku v 20-tych rokoch 20. storočia.

Akademická úloha pedagogiky nie je podla môjho názoru vôbec odlišná od úlohy akejkol'vek vedy: Má poznávat', nie kritizovat' a reformovat', nie pripravovat' na prax alebo viest' k činnosti inej, akou je opät' pedagogické bádanie a poznávanie ako také. (Fischer, 1969, s. 251)

Vedecké, explanatívne preverenie normatívnych postulátov pedagogiky vedie k spochybneniu normatívnej pedagogiky ako takej. Takýto myšlienkový experiment $\mathrm{s}$ bežne prijímanými normatívnymi postulátmi pedagogiky vykonal Lenzen (1999). Analyzujúc východiská a dôsledky rôznych nosných postulátov dospel k nasledujúcemu záveru.

Normatívna pedagogika, t.j. odvodenie odporúčaní pre konanie z najvyšších noriem, nefunguje, pretože empirické nezávisle premenné vedú $\mathrm{k}$ tomu, že sa realizujú úplne iné normy ako tie zamýšlané. Normatívna pedagogika však nie je len dysfunkčná, ale má aj tendenciu otvárat' dvere dokorán politickému zneužívaniu. (Lenzen, 1999, s. 29)

Na základe vyššie uvedeného Dietrich (1998, s. 16) uzatvára, že „pedagogiku ako vedu“ možno chápat' predovšetkým ako nenormatívnu „teóriu“. Cesta utvárania vedeckej teórie vedie podla neho v pedagogike cez tri štádiá. Prvé štádium predstavujú poznatky o výchove, ktoré má človek na základe svojich vlastných skúseností, spomienok na výchovu či uplatňovaných výchovných praktík. Tieto poznatky vedú $\mathrm{k}$ „výchovnému umeniu“ či majstrovstvu. To je vysoko individualizované a subjektívne. Druhé štádium predstavuje snaha o zovšeobecnené poznanie o výchove vychádzajúce aj zo skúseností iných, ich zist'ovania, porovnávania, vyhodnocovania. Na tomto poznaní sú založené výchovné príručky sprostredkujúce „výchovné ponaučenia“ či náuku. Tretiu fázu tvorí snaha o systematizáciu poznania, ked' sa výchovné skutočnosti preskúmavajú v samotných svojich základoch, ked’ sa odpútavajú od bezprostrednej praxe a smerujú k imanentným súvislostiam a predpokladom. Až toto štádium predstavuje teritórium vedeckého poznania. Až v rámci tohto štádia je možné „ozrejmit' predchádzajúci vztah predvedeckej teórie k praxi“ (Tschamler, 1996, s. 112). 
Sayler (1968) hovorí dokonca o piatich štádiách pedagogickej teórie. $\mathrm{V}$ situáciách angažovaná teória prvého štádia pracuje $\mathrm{s}$ individuálnym (pred)porozumením výchove, situačne podmienená teória druhého štádia sa chápe ako prirodzená teória skúsenosti, hypotetická teória sa snaží o usporiadanie a zaradenie výchovných skúseností a vedecká teória sa stáva situačne rozšírenou a abstrahujúcou od priestorovo-časových podmienok konania, aby vyústila do piateho štádia situačne nezávislej teórie, ktorá ako výchovná múdrost’ nadväzuje na tradíciu.

\section{$5 \quad$ Teória a prax v genéze disciplíny}

Karteziánska idea „teórie praxe“, ktorá komplikuje aristotelovský model, skomplikovala aj status pedagogiky (ako aj iných sociohumanitných vied). Táto medzníková a nekomfortná poloha pedagogiky, poloha medzi teóriou a praxou, je vyjadrená aj v jej statuse sociohumanitnej vedy. Dá sa stále zotrvat' na otázke, či ide o humanitnú alebo sociálnu vedu. Dietrich (1998, s. 291) dokonca hovorí o „filozoficko-empirickej vede orientovanej na konanie“. Dilthey zase priradil pedagogiku k „duchovno-vedným“ disciplínam. Vychádzal pritom z metodologického rozdielu medzi „vysvetlujúcimi“ (prírodnými) a „rozumejúcimi“ (duchovnými) vedami. Pedagogika nie je podla neho vysvetl'ujúcou vedou, ale vedou, prostredníctvom ktorej sa objektom jej skúmania dá porozumiet' (nie ich však vysvetlit'). Hermeneutika bola pre neho cestou takéhoto porozumenia. No nejasná pozícia pedagogiky vychádza aj z jej oneskorenosti, čo priamo hovorí Tenorth (1989), ked' pedagogiku, inštitucionalizujúcu sa až začiatkom 20. storočia označuje ako „oneskorenú“ disciplínu. Pedagogika je od svojho vzniku

konfrontovaná so skutočnost'ou, že daný predmet skúmania, okolo ktorého sa prostredníctvom systematickej reflexie ako samostatná vedecká disciplína predsa snaží profilovat', je už dávno spracovávaný inými disciplínami a vôbec nie bezúspešne. (Rieger-Ladich, 2007, s. 164)

Kantove prednášky z pedagogiky, Schleiermacherove pedagogické tézy, Simmelova obsiahla prednáška o školskej pedagogike - to všetko svedčí o pedagogických komponentoch filozofie, teológie či sociológie. Prvú katedru pedagogiky vo Francúzsku na univerzite Bordeaux viedol slávny sociológ Durkheim, pričom po jeho odchode na Sorbonne v roku 1902 tu opätovne niekol'ko rokov viedol novo založenú katedru pedagogiky. Bernfeldove tematizácie pedagogiky z pozície psychoanalýzy zaznamenali taktiež značný ohlas. Závis- 
lost' pedagogiky od filozofie, neskôr sociológie a následne psychológie z nej vždy robilo oneskorenú a závislú disciplínu.

Exemplárnym vyústením problémov autonomizácie pedagogiky, nejasnosti vztahu teórie a praxe či statusu pedagogiky ako disciplíny bolo celonemecké, spočiatku empiricko-analyticky vyprofilované hnutie za etablovanie tzv. „vedy o výchove“ (Erziehungswissenschaft) ako vedeckého protipólu predvedecky a prakticisticky orientovanej „pedagogiky“, ktorej prototypom bola duchovno-vedná pedagogika (Lenzen, 1999). V 60-tych rokoch 20. storočia išlo o pomerne významný t’ah, pretože nastávali sociálne zmeny rôznorodého charakteru a novo vznikajúca disciplína sa im mohla lepšie - v porovnaní s obsahovým tradicionalizmom zabehaných akademických disciplín prispôsobit'. Veda o výchove tak získava svoje nové špecifické sociálne úlohy, ktoré sa však následne stanú jej limitujúcim faktorom, najmä v prípade politizácie vedy o výchove. Tá (najmä v dôsledku sociálnej dynamizácie nových sociálnych hnutí), v podobe tzv. kritickej vedy o výchove ovplyvnenej najmä Frankfurtskou školou, pomerne rýchlo vystrieda empiricko-analytickú vedu o výchove. $\mathrm{V} 70$-tych rokoch 20 . storočia tak nastáva situácia, že ani v rámci vedy o výchove „neprebehol dostatočný čas a nebola dostatočná príležitost' akumulovat' pedagogické vedenie potrebné pre vedecké spracovanie prípadných reformných želaní" (Lenzen, 1996, s. 11). Nový teoretický začiatok tak dostal zásadné trhliny.

Vztahah teórie a praxe vo vývoji stredoeurópskej pedagogiky/vedy o výchove sa odvíja práve od týchto disciplinárnych pohybov. Duchovno-vedná pedagogika išla cestou „teórie praxe a pre prax“ (Tschamler, 1996, s. 112). V jej podaní má pedagogická veda fungovat' deskriptívne a normatívne voči praxi. Deskriptívne má opisovat' výchovnú skutočnost'. Ked'že každý opis má jazykovú podobu, ide vždy o interpretáciu skutočnosti. Interpretácie budujú teórie, ktoré napr. prostredníctvom stanovovania cielov výchovné procesy spätne normujú. Dôležitá je tu komplexná miera porozumenia výskumníka výchovnej praxi, pričom sa ráta s jeho subjektívnym predporozumením a subjektívnymi interpretáciami. Empiricko-analytická veda o výchove 60 -tych rokov 20. storočia toto pedagogické ponímanie striktne kritizuje ako nevedecké. Teória sa chápe ako pomerne nezávislá od praxe. Jej budovanie podlieha striktne vedeckej logike, z jej budovania sa eliminujú subjektívne a situačné momenty. Aplikácia teórie $\mathrm{v}$ praxi sa neponíma ako úloha výskumníkov. Oni nemajú byt' zodpovední za teoretický transfer. Typický 
je odstup od pedagogických aplikácií a od sféry praxe. Teória sa nechápe ako závislá od výchovných situácií, ale ako nadsituačná (Tschamler, 1996). Kritická veda o výchove inštalujúca sa v priebehu 70 -tych rokov 20. storočia (v čase búrlivého sociálneho akcionizmu) sa opätovne viac upína k praxi, predovšetkým k politickej praxi ako prostriedku sociálnej transformácie. Úlohou vedy nie je len skúmat' prax a teoretická angažovanost' v praxi, ale priamo navodzovanie zmien v praxi. Kritická veda o výchove má dištancovaný postoj voči oddeleniu teórie ako výskumu, a praxe ako konania. Vedecké konanie a praktické konanie majú tvorit' jednotu (vel'mi často sa používa obraz „dialektickej“ jednoty teórie a praxe). Preto sa aj prvotným záujmom vedy o výchove má podla stúpencov kritickej pedagogiky stat’ vzdelávacia politika.

\section{Praktické obraty $\mathrm{v}$ pedagogike}

Silná náchylnost' pedagogiky/vedy o výchove prijímat' nové spoločenské imperatívy tak, ako sa začali akademicky profilovat' koncom 60-tych a v 70-tych rokoch 20. storočia, svedčí jednak o sociopolitickej závislosti a neautonómnosti disciplíny a zároveň o častých osciláciách jej vedeckých orientácií a záujmov. V 80-tych rokoch 20 . storočia sa tak európska veda o výchove nachádza v situácii, že

„namiesto nového teoretického začiatku... nastúpil jednoduchý prakticizmus“, ktorého výsledkom bola „Vzniknutá neschopnost' alebo prinajmenšom strata ochoty druhej generácie študentov po roku 1968 chápat’ teoretickú prácu ako kritiku, ktorá sa až v druhom kroku stáva ,praktickou“ “. (Lenzen, 1996, s. 11-12)

Prakticizmus možno chápat' ako dôsledok už spomenutého fenoménu oneskorenosti pedagogiky. $\mathrm{V}$ časoch, kedy sa empiricko-analytický prúd $\mathrm{v}$ pedagogike snažil rozvíjat’ fundovaný výskum, sa už v Európe viedol rozvinutý spor o pozitivizme sociálnych vied, ktorý predznamenával skoré opustenie pozitivistických stanovísk v sociálnych vedách. Ako v nadväznosti na Kuhna hovorí Lenzen (1996), empiricko-analytická pedagogika sa oproti iným sociálnym vedám nemala čas dostat’ do paradigmatickej fázy „normálnej vedy“. Politicky angažovaná kritická veda o výchove v tejto destabilizácii pokračovala dalej, takže pedagogika / veda o výchove nevyústila do fázy tvorby teórie. 
Viazanost' vedy o výchove na sociálnovedné pohyby a jej ateoretickost' viedli k svojskému uchopovaniu sociálnovedných teórií a metód:

V rámci vedy o výchove tak metodologické koncepty, ako aj teórie a pojmy sociálnych a kultúrnych vied, zjavne zažívajú špecifický transformačný proces. Jeho všeobecným vzorom sa zdá byt' to, že teoretické ponuky zvonka sa v rámci vedeckej pedagogiky smerujú prakticisticky, zažívajú normatívne preformulovanie a spravidla bývajú pozbavené ich striktne analytického charakteru. (Tenorth, 1996, s. 175)

Pôvodné disciplíny, ako napr. sociológia, chápu takúto transformáciu ako typicky pedagogickú a v nadväznosti na vlastnú akademickú genézu ju často chápu ako vecne nelegitímnu a ako prejav neadekvátneho uchopenia, či dokonca teoretickej nekompetentnosti pedagogických disciplín (Lautmann \& Meuser, 1986).

\subsection{Obrat ku každodennosti vo výskume}

V 80-tych rokoch 20. storočia pedagogika nad'alej rozvíjala svoju prakticistickú orientáciu, najmä v podobe tzv. obratu ku každodennosti vo vedách o výchove (Thiersch, 1978). Tak ako bol obrat ku kritickej vede o výchove reakciou na vývoj $v$ sociológii a sociálnej filozofii reprezentovaný najmä tzv. Frankfurtskou školou, aj v prípade obratu ku každodennosti bola veda o výchove opät' reaktívnou a oneskorenou disciplínou. V Nemecku išlo predovšetkým o reakciu na Bielefeldskú skupinu sociológov, najmä na A. Schütza. V globálnejšom kontexte išlo o metodologický obrat nadväzujúci na $\mathrm{A}$. V. Cicourela a $\mathrm{H}$. Garfinkela a ich metódy orientované na každodennost', ktoré otvárali cestu aplikácie etnometodológie a etnografie $\mathrm{v}$ rámci rôznorodých sociálnych vied. $\mathrm{V}$ otázke problematiky vztahu teórie a praxe zohral obrat ku každodennosti zneprehladňujúcu úlohu, pretože zaviedol analógiu s pojmovým dualizmom teória - prax v novom dualizme veda - každodennost'. Vytvorila sa predstava, že s posilnením orientovanosti na každodennost' sa získa aj vyššia praktická relevantnost' pedagogického výskumu. Lenzen (1996) však upozorňuje, že o ide vel'mi zjednodušenú a neadekvátnu predstavu, ktorá o nič bližšie neprivádza teóriu k praxi.

Možno teda vel'mi prehnane povedat', že problém teórie a praxe je z pohladu orientácie na každodennost' vlastne problémom teórie a teórie, teda problémom dichotómie medzi vedeckými a každodennými teóriami o výchovných procesoch. (Lenzen, 1996, s. 53) 
Obrat ku každodennosti bol aj našou pedagogikou prijatý ako vhodná alternatíva ideologicky fundovanej pedagogiky z pred roku 1989 a začal sa empiricky rozvíjat' začiatkom 90 -tych rokov 20 . storočia v podobe systematického budovania prúdu školskej etnografie a entuziazmu z tzv. kvalitatívnej metodológie pedagogického výskumu. $Z$ vel'kej časti však tieto pohyby zostali uzavreté $\mathrm{v}$ medziach prílišnej situačnosti, teda singulárnych teórií každodennosti. $\mathrm{V}$ akomsi kontrastnom bilancovaní tohto československého metodologického pohybu sme už na inom mieste konštatovali, že takto orientovaný výskum sa začal nadmieru orientovat' na autorskú originalitu a na atraktívnost' témy, čo v konečnom dôsledku zabraňuje tomu, aby tvrdo odvedená výskumnícka práca spela k širšiemu celku teoretického pedagogického poznania. Tento typ výskumníckej práce môže roztrieštit' disciplínu pedagogického poznania do mozaiky drobných a izolovaných výpovedí bez toho, aby sme na konci boli vôbec schopní čosi syntetické povedat' (Pupala, 2010). Emblematickým vyjadrením týchto prístupov je presadzovanie sa autorskej singularity v písaní výskumných správ, ktorá má ešte viac podčiarknut' singulárnost' výskumných tém a arbitrárnost' ich vol'by.

\section{Teória a prax v učitel'skej profesii}

Jedno z najväčších zrkadiel, v ktorom sa zretel'ne odráža existujúca podoba problémov vztahu teoretického a praktického $\mathrm{v}$ pedagogickom prostredí je oblast' vzdelávania učitelov. Táto oblast' je totiž akýmsi nevyhnutným priesečníkom toho, čo je (alebo chce byt') teoretické a toho, čo je zo svojej podstaty praktické - a to najmä v situácii, ked' sa vzdelávanie učitel'ov situuje do akademického, univerzitného prostredia. Teória $v$ tejto situácii spravidla a principiálne čelí kritériu, do akej miery je užitočná pre praktické profesijné potreby učitelov, frekventanti učitel'ského vzdelávania (či už študenti na univerzitách, ale aj učitelia $\mathrm{v}$ činnej praxi podrobujúci sa rozmanitým vzdelávacím aktivitám v rámci ich kariérneho postupu) sa stávajú dôležitou položkou posúdenia toho, čo je vhodná a rozumná teoretická disciplína. Sila tohto referenčného kritéria má prinajmenšom nasledovné príčiny: 1. Vo všeobecnosti je odrazom modernistického obratu chápania teórie inštrumentálne sa vztáahujúcej k potrebe „zdokonalovania“ praxe; 2. Viaže sa na zmieňovanú „oneskorenost"“ pedagogiky, ktorá súvisí aj s tým, že úsilie produkovat' pedagogickú teóriu je „vynúteným úsilím“ v tom slova zmysle, že ho iniciujú najmä potreby vzdelávania učitel'ov v akademických podmienkach; 3 . Neustále sa reprodukujú požiadavky na praktickú orientáciu 
prípravy učitelov, ktorá v súčasnosti, pod vplyvom neoliberálneho obratu k užitočnosti, nadobúda na novej intenzite - orientácia na prax sa tak stáva kritickým sitom pre teóriu.

Ako sme už na iných miestach ukázali, neoliberalizácia pedagogiky, ktorá v Európe silnie od konca 90-tych rokov 20. storočia, vedie k zásadnému prebudovávaniu všetkých úrovní pedagogického priestoru a pedagogického poznania (Kaščák \& Pupala, 2011). Prax a teória sa majú v novej podobe prepojit' $\mathrm{v}$ takých prístupoch, ako je napr. prístup založený na dôkazoch (evidence-based approach), ktorého základný predpoklad predstavuje praktická relevancia pedagogického poznania a sumarizácia $\mathrm{v}$ praxi získavaných údajov. Vel'ká čast' akademického pedagogického poznania sa $\mathrm{z}$ tohto pohl'adu javí ako prakticky irelevantná, čo vedie k odporúčaniam na zmeny $\mathrm{v}$ akademickej príprave učitel'ov. Permanentné tlaky na reformu učitel'ského vzdelávania sú tak súčasne a znovu sprevádzané heslami o „prakticky orientovanom prístupe“ (work-based approach), o jeho podpore cez konktraktáciu univerzitného prostredia so svetom školskej praxe cez praktické supervízie (etablovanie school-based supervising, mentor teachers) a cez všeobecnú podporu prepájania univerzitného vzdelávania učitelov so svetom práce a s pracovným trhom (EK, 2007). Prezieravejšie analýzy takýchto trendov $\mathrm{v}$ súčasnosti však otvorene varujú, že presadzované partnerstvá s praxou môžu viest' k regresnému presunu t'ažiska prípravy učitel'ov na samotný sektor cvičných škôl (Bloomfield, 2008) a že univerzity a vzdelávanie učitelov na nich nezvratne poznačuje anitiintelektualizmus (Liesner, 2006) a odklon študentov od väzieb na akademické poznávanie (Pritchard, 2005).

\subsection{Vytváranie reflektujúceho praktika}

Treba súčasne pripomenút', že vel'ký neoliberálny obrat vzdelávania učitel'ov sa nemanifestuje len politickými opatreniami, ale, ako na to upozorňujú Olssen a Peters (2005), zakladá aj novú teoretickú a epistemologickú infraštruktúru budovania učitel'skej profesionality. Trauma z permanentnej tenzie medzi teóriou a praxou, ktorá je v pedagogickom prostredí prítomná prinajmenšom od čias, kedy zovšeobecnela univerzitná príprava učitel'ov, sa začína oslabovat': Obrovskou nádejou a novou epistemologickou perspektívou sa už od 80-tych rokov minulého storočia stáva model „reflektujúceho učitel'a“ či „reflexívnej výučby“, ktorých leitmotívom je pokus o vyvodenie teoretického zo samotného praktikujúceho subjektu, či produkovanie teore- 
tického samotným týmto subjektom. Koncept „reflektujúcich praktikov“ akoby mal preklenút' tradičnú priepast' medzi teoretickým a praktickým tým, že praktikujúci subjekt je subjektom, ktorý sám produkuje teoretické poznanie, čím sa takýto subjekt stáva automatickou poistkou úspešnej validizácie teoretického cez osobnú skúsenost'. Literatúra o „reflektívnej výučbe“ a o praktikách „reflektujúcich učitelov" dnes obsahuje nespočetné množstvo položiek a od 90-tych rokov minulého storočia sa odkaz na prípravu „reflektujúcich učitel'ov" aj v našich podmienkach povinne objavuje v každom epizodickom i systémovom návrhu na zmeny v príprave učitelov (na Slovensku aj v tom ostatnom, pozri Návrh, 2012). Aj ked’ vo všeobecnosti model „reflektujúceho učitela" naznačuje silný príklon k legitimizácii deliberácie ako forme teoretického poznávania vo vzt’ahu k pedagogickému konaniu, a inklináciu k chápaniu pedagogického poznania ako fronesis, literatúra vztahujúca sa k doméne „reflexie“ v pedagogike naznačuje, že skôr ako o presvedčivý koncept ide o populárnu tému vo výskume učitel'stva a v politike učitel'ského vzdelávania, a o „akademickú cnost', ku ktorej je slušné sa v akademickom prostredí hlásit'. Táto téma totiž dnes obsahuje najmä prepletený mix agendy a odkazov s úplne nejasným vztahom k zásadnej otázke - čo znamená pre epistemológiu pedagogického myslenia a s akou schémou vzt'ahu teórie a praxe reálne pracuje. Na túto skutočnost' naráža napr. genealogická štúdia reflexie v učitel'skom vzdelávaní (Fendler, 2003) zameraná na rekonštrukciu variantných zdrojov konceptualizácie reflexie v učitel'stve s odkazom na to, že súčasná zmes štúdií o tejto téme stratila historické súvislosti, stala sa ahistorická a metodologicky zahmlená. Pri historickom štúdiu populárneho konceptu reflexie v učitel'stve štúdia odkazuje na jeho štyri významné zdroje, pričom však každý z nich má odlišný dopad na konštrukciu reflektivity a denaturalizuje jej podstatu v takom zmysle, ako sa jej v súčasnosti pripisuje.

Prvým zdrojom je karteziánska racionalita pracujúca s predpokladom, že seba-uvedomenie môže produkovat' validné porozumenie. Žiaduca sa stáva každá reflektivita, pretože demonštruje vedomie seba, pričom „self“ je subjekt v simultánnej hre - je subjektom, ktorý reflektuje, a je objektom, ktorý je reflektovaný. Za zmysel reflektivity v pedagogickom prostredí sa považuje možnost' racionálnej a zodpovednej vol'by, takže ciel'om reflektivity je zodpovedné konanie zosúladené s myslením. Ako upozorňuje Fendler, paradoxné však je, ked' sa takéto poňatie reflektivity začne spájat' s formalizáciou a vyprodukuje metodickú schému fáz reflektivity učitela 
krok po kroku (ako napr. model ALACT ${ }^{12}$ ), ktorá sa stáva dokonca ironickou, ak sa berie do úvahy deweyovská tradícia stavajúca reflexiu ako alternatívu k inštrumentálnemu spôsobu myslenia. Vôbec neprekvapuje kritika, ktorá voči takémuto chápaniu reflektivity namieta, že fascinácia reflektivitou obchádza napr. kritériá kvality reflexie, ako aj stanovenie miery, do akej by učitel'ská deliberácia mala do seba inkorporovat' kritiku sociálneho a inštitucionálneho kontextu, v rámci ktorého je produkovaná (Zeichner, in Fendler, 2003).

Minimálne $\mathrm{v}$ prostredí USA má do súčasnosti $\mathrm{v}$ diskurze o reflektivite významný vplyv práve John Dewey (najmä jeho dielo z roku 1933). Situovanost' deweyovskej tradície do progresivistickej éry pedagogických reforiem však podl'a Fendler (2003, s. 18) upozorňuje na špecifické chápanie reflektivity v tejto tradícii: Kým „karteziánska reflexia je uzákonením seba-uvedomenia, Deweyho reflexívne myslenie mienilo nahradit' vášeň a impulzy vedeckou racionálnou vol'bou“. Bolo súčastou éry, ktorá manifestovala rozlahlé zmeny sociálnych organizácií práce a usilovala o poznanie cez budovanie štruktúrovaných komunít expertov (Popkewitz, 1987). Pedagogická teória v tejto ére mala posilnit' profesionalitu vyučovania a samotná profesionalita bola spojená s vedou a s vedeckými metódami. Netreba však osobitne zdôrazňovat', že hoci súčasné verzie učitel'skej reflektivity a s ňou spojené vnímanie profesionalizmu môžu deklaratívne nadväzovat' na Deweyho progresivistickú tradíciu, tie sú od nej už vel'mi vzdialené a zmenili svoj význam. V tomto posune zohral podstatnú rolu tretí zdroj konštrukcie učitel'skej reflektivity - Schönova štúdia o profesionálnom poznaní (1983).

V porovnaní s deweyovskou ideou reflektivity tu ide o d’alší kontrast. Schön totiž prichádza s ideou profesionalizmu založenom na reflektivite $\mathrm{v}$ akcii, pričom v jeho podaní reflektivity sa pripisuje vysoká hodnota každodennému intuitívnemu poznaniu. Reflektivita $\mathrm{v}$ tomto poňatí sa nachádza na pomedzí umenia a vedy a je opozitom striktného vedeckého poznania a vedeckej racionality. A aj ked' by sa dali zahrnút' Deweyho a Schönov odlišný prístup k reflektivite pod spoločného menovatel'a odmietania inštrumentálnej

2 Model ALACT, vytvorený za účelom podpory reflektivity študentov učitelstva, formalizuje fázy idealizovaného procesu reflexie do cyklického procesu piatich po sebe nasledujúcich krokov: A (action), L (looking back on action), A (awareness of essential aspects), C (creating alternative method of action), T (trial). Autorsky je tento model spojený s holandským autorom M. Korthagenom a jeho spolupracovníkmi (Korthagen et al., 2001) - v češtine teraz dostupný v preklade: Korthagen et al. (2011). 
a technokratickej racionality, Fendler hovorí o tom, že tieto prístupy sa príliš rozchádzajú, aby sa dali vnímat' komplementárne, obzvlášt' ked' sa v reflexívnej praxi chce dat' dohromady vedecká expertíza s intuitívnou neistotou:

Schönov diskurz o intuitívnom reflektujúcom praktikovi protirečí Deweyho asociácii relexívneho myslenia založeného na vedeckej metóde. Schön obhajuje prakticky založené všedné poznávanie a odmieta vedecké a intelektuálne poznanie ako príliš „teoretické“... V súčasnosti je význam profesionálnej reflexie preplnený napätím medzi Schönovým pojmom praktickej intuície na jednej strane a Deweyho poňatím racionálneho a vedeckého myslenia na strane druhej. (Fendler, 2003, s. 19)

\subsection{Rozpornost'v rétorike o reflektujúcich učiteloch}

Berúc do úvahy aj štvrtý zdroj súčasného diskurzu o reflektivite - kultúrny feminizmus ${ }^{13}$, máme v súvislosti s témou reflexívneho učitela a reflexívnej výučby pred sebou skutočne tažko čitatel'ný smer, ktorý síce chce dat' novú podobu vztahu teórie a praxe v sektore výchovy a vzdelávania, avšak namiesto ujasnenia plodí viaceré paradoxy a kontraproduktívne dôsledky. Fendler upozorňuje napr. na to, že rétorika o učitel'och ako o reflektujúcich praktikoch chce na jednej strane posilnit' status a autentickost' učitel'skej profesie, na druhej strane je ironické, že požiadavka na učitel'ov, aby absolvovali prípravu na reflexívnu výučbu, stojí na predpoklade, že učitelia nie sú schopní reflektivity bez priameho vedenia expertnými autoritami.

Nejasnou zostáva aj povaha poznania dosiahnutá reflexiou, pretože rôzne uhly výkladu umožňujú legitimovat' ako produkt reflexie raz expertné, inokedy anti-expertné poznanie. Rovnako je paradoxom či dokonca epistemologickou iróniou, ked’ sa v mene profesionality učitela jedným dychom rozvíja paralelný diskurz o učitelovi ako reflexívnom praktikovi so svojim prakticky založeným poznaním na jednej strane a o štandardizácii učitel'skej profesie, v ktorej sa robí odpočet zvládania istého typu externalizovaných poznatkov (u nás pozri napr. Kasáčová \& Kosová, 2007) na strane druhej. Webb (2007) v tejto súvislosti hovorí o exteritorializácii a deteritorializácii učitel'ského poznania, ked’ sú učitelia vo svojom profesijnom vývine orientovaní na výko-

13 Na rozdiel od liberálneho feminizmu kultúrny feminizmus (inak nazvaný aj vztáahový feminizmus alebo feminizmus „iného hlasu“) zdôrazňuje odlišnost' ženského pohladu a obhajuje jeho priestor. Z hl'adiska reflexie ide potom o to, že umožňuje potlačit' myslenie socializované „mužským princípom“ a prispieva k vytvoreniu predpokladov na uvažovanie v kontakte s vlastným vnútrom a „vlastnou inteligenciou“. 
ny zakomponované do logiky štandardizácie profesie. Avšak - strategicky, exteritorializácia poznania obetuje reflexiu, neistotu, dialóg a objasnenie učitel'ovho spôsobu pýtania sa, ako aj situovanost' diagnózy, ktorá hovorí o tom, aký v danej chvíli učitel' je. Takže prepojenie požiadavky na ovládanie istého typu poznania definovaného externou autoritou v podobe štandardu celkom protirečí idey učitela - reflektívneho praktika v zmysle jeho poznania ako fronesis, alebo sa predpokladá model teoretického poznania ako normatívnej teórie nezávislej na „reflektujúcom praktikovi“. Alebo - čo je vel'mi pravdepodobné - spájaním konceptu reflexívneho praktika a jeho situačných teórií so štandardizáciou profesijných zdatností sa len potvrdzuje plytkost’ súčasného „reflexívneho" diskurzu na tému väzby teoretického a praktického v učitel'skom vzdelávaní a jeho nízky potenciál tento vztah akokolvek produktívne uchopit’ voči kritikám, ktoré sa voči tomuto vzt’ahu vznášajú.

Kritické hladisko guvernmentality (bližšie Kaščák \& Pupala, 2010) zase ponúka pohlad na reflexiu ako na technológiu seba-disciplíny a seba-spravovania (to naznačuje tiež Fendler, 2003). Nie je napríklad možné diferencovat' medzi reflektujúcim subjektom a reflektovaným objektom, rovnako ako nie je možné vidiet' priame spojenie medzi autentickým skúsenostným pozadím reflexie a tým, čo sa $v$ reflexii objavilo na základe už socializovaného poznania. Reflexia teda obsahuje nebezpečenstvo, že neprezradí nič viac, len čo už bolo poznané. Vo foucaultovskom slova zmysle potom učitel'ská reflexia môže fungovat' presne ako disciplinačná technológia, ktorá je produkovaná praktikami disciplinácie a normalizácie.

Koncept „reflexívneho učitel'a“ v ostatnom období zjavne inklinoval k tomu, aby v pedagogike potlačil či už jej normativitu alebo abstraktnost' nezodpovedajúcu praktickým otázkam učitel'ov a posilnil v nej deliberatívnu dimenziu intímnejšej fronesis. Na poli pedagogickej metodológie túto snahu sprevádzalo paralelné presadzovanie tzv. akčného výskumu, ktorý mal rovnako prispiet' k premosteniu teoretického a praktického $\mathrm{v}$ pedagogickom sektore. A to najmä tým, že sa očakáva, aby aktérmi tohto výskumného prúdu boli najmä učitelia, pre ktorých sa akčný výskum stane sofistikovanejším nástrojom pre dôkladnejšiu reflexiu a hlbšie porozumenie vlastnej práce, spolu s tým, aby sa takýto výskum stal nástrojom priameho ovplyvňovania pedagogickej praxe. Predpokladá sa tak teória pochádzajúca priamo z praxe, vztahujúca sa na praktické otázky a aplikovatel'ná hned' do praxe. Spolu s povzbudzovaním kvalitatívnych prístupov k výskumu pedagogickej reality 
si cestu preráža orientácia na situačnost' praxe a epizodická kumulovanost' poznania centrovaná na praktické situácie. Kumulácia teoretického a vedeckého poznania ako takého prestala byt' zaujímavým cielom intelektuálnej a poznávacej činnosti, pričom sa oslabila aj pôvodná modernistická ambícia, ktorá, síce práve s úsilím posilnit’ intervenčný vplyv teórie na prax, sa mala realizovat' na báze prísnejších kritérií na vedecké poznanie v sociohumanitných disciplínach.

\section{Záverečný obrat: návrat k intelektu}

Vzdelávanie učitel'ov orientované na prax je základnou politickou agendou EÚ vyjadrovanou na úrovni autoritatívnych politických dokumentov a prehlásení, a to najmä vo väzbe na Lisabonskú stratégiu. Spolu s epistemologickým obrazom učitel'a - reflektujúceho praktika - ide o východiskové body, na ktorých v európskych krajinách stoja manifesty transformácie učitel'ského vzdelávania a ktoré aj reálne tvarujú súčasný vývoj programov tohto vzdelávania. „Reflektujúci praktik“ uväznený v pretláčajúcom sa štandardizovanom obraze učitel'skej profesie redukuje nielen teoretizujúci potenciál požadovanej reflektivity učitel'a, rezignuje však aj na možnost' rozumného balansovania medzi teoretickým a praktickým modusom profesie. Nie je tažké predvídat' paradoxné dôsledky dnešných snáh o zmenu v učitel'skej príprave: Tento typ prípravy postupne povedie študentov k čisto praktickým a úradníckym profesijným identifikáciám neumožňujúcim im opätovne získat’ status spoločensky významnej skupiny intelektuálov (Kaščák \& Pupala, 2012). Vo vzt'ahu $\mathrm{k}$ tu sledovanej téme možno vyslovit' len nasledovné: Požiadavka súčasnej kritickej pedagogiky, aby učitelia opustili svoje identifikácie ako technológov vzdelávania a stali sa „transformatívnymi intelektuálmi“ (Giroux \& McLaren, 1996) si vyžaduje opätovnú rekonštrukciu teoretického poznania v aristotelovskom zmysle slova. Príklad takejto rekonštrukcie poskytla v nedávnom rozhovore pre český časopis Studia Paedagogica jedna z najväčších súčasných autorít kritickej sociológie vzdelávania S. J. Ball (Pokus o teorii nepořádku, 2011):

... chcem sa spojit's učitel'mi ako s intelektuálmi. Jedna z vecí, ktoré robím, ked' ma pozvú prednášat' učitel'om, je, že učím učitel'ov používat' teóriu. Hovorím s nimi prostredníctvom Foucaulta a Bourdieua. Nehodlám s nimi zaobchádzat' tak, ako by to nemohli pochopit' a zapojit' sa. Takže ked' ma ludia pozvú, hovorím - áno, vel'mi rád prídem, ale nebudem hovorit' inak, ako by som hovoril so skupinou študentov doktorandského štúdia... Myslím, že pokial’ sa neposunieme týmto 
smerom a nedospejeme $\mathrm{k}$ tomu, tak zredukujeme pedagogický proces na rovnaký proces technizácie, aký prebieha $v$ iných oblastiach pedagogiky, $v$ iných oblastiach sociálnej praxe. Skôr ako praktizujúcimi intelektuálmi budeme technikmi, ktorí vedia niekol'ko vel'mi základných vecí...

Spojenie výskumníka a učitela v tejto podobe je aj formou efektívnej komunikácie vedy a praxe. Táto forma neruší hranice vedy a praxe, je však špecifickým premostením opodstatnene a prirodzene diferencovaných svetov. Mostom, cez ktorý sa táto komunikácia deje je intelekt, ktorý udržiava pri živote produkciu vedeckého poznania a dáva aj živnú pôdu spoločenskej sile učitela a jeho praktického konania ako profesionála a ako sociálne angažovaného človeka. Toto spojenie vedy a praxe a takýto typ komunikácie medzi vedou a praxou sa učitelov dotýka dvakrát: Prvýkrát v sieti ich každodenných učitel'ských činností so žiakmi v triede pri komunikácii vzdelávacích obsahov, druhýkrát pri vytváraní vlastnej profesijnej identity v sociálnej sieti iných profesijných identít a ich vzájomných vzt’ahov. Na priesečníku týchto dvoch sietí, ktoré iniciujú diferencované spôsoby intelektuálnych aktivít, sa otvára špecifický priestor na intelektualizáciu učitel'skej profesie ako program, ktorý má šancu vyviest' existujúcu agendu regulácie učitel'stva zo slepej uličky.

\section{Literatúra}

Altrichter, H., Kannonier-Finster, W., \& Ziegler, M. (2005). Das Theorie-Praxis-Verhältnis in den Sozialwissenschaften im Kontext professionellen Handelns. Österreichische Zeitschrift für Soziologie, 30(1), 22-43.

Andresen, S. (2007). Grenzen der Anerkennung - Anerkennung der Grenzen. In N. Ricken (Ed.), Über die Verachtung der Pädagogik. Analysen - Materialien - Perspektiven (pp. 121-136). Wiesbaden: VS Verlag für Sozialwissenschaften.

Arendt, H. (1998). The human condition. Chicago: The University of Chicago Press.

Aristoteles (1972). Metafyzika. In Antológia z diel filozofov. Od Aristotela po Plotina. Bratislava: Epocha.

Aristoteles (1979). Etika Nikomachova. Bratislava: Pravda.

Aristoteles (1988). Politika. Bratislava: Pravda.

Aubenque, P. (2003). Rozumnost podle Aristotela. Praha: Oikoymenh.

Beck, U., \& Bonß, W. (1989). Verwissenschaftlichung ohne Aufklärung? Zum Strukturwandel von Sozialwissenschaft und Praxis. In U. Beck \& W. Bonß (Eds.), Weder Sozialtechnologie noch Aufklärung? Analysen zur Verwendung sozialwissenschaftlichen Wissens (pp. 7-45). Frankfurt am Main: Suhrkamp Verlag.

Bloomfield, D. (2008, červenec). Neo-liberal accreditation agendas: Challenge and opportunities for professional experience, Paper presented at the ATEA conference, Sunshine Coast. Dostupné z http://www.aare.edu.au/08pap/blo08372.pdf 
Bohman, J. F., Hiley, D. R., \& Shusterman, R. (Eds.). (1991). The interpretive turn: Philosophy, science, culture. Ithaca: Cornell University Press.

Dewey, J. (1933). How we think: A restatement of the relation of reflective thinking to the educative process. New York: D.C. Heath and Company.

Dietrich, T. (1998). Zeit- und Grundfragen der Pädagogik. Bad Heilbrunn: Klinkhardt.

Díogenés Laertios (1995). Životy, názory a výroky proslulých filosofů. Pelhřimov: Nová tiskárna.

EK (2007). Improving the quality of teacher education. Brussels: Commision of the European Communities.

Fendler, L. (2003). Teacher reflection in a hall of mirrors: Historical influences and political reverbations. Educational Researcher, 32(3), 16-25.

Feyerabend, P. (1980). Erkenntnis für freie Menschen. Frankfurt am Main: Suhrkamp Verlag.

Fischer, A. (1969). Über das Studium der Pädagogik an den Hochschulen. In F. Nicolin (Ed.), Pädagogik als Wissenschaft (pp. 244-267). Darmstadt: Wissenschaftliche Buchgesellschaft.

Flyvbjerg, B. (2001). Making social science matter. Cambridge: Cambridge University Press.

Gadamer, H.-G. (2010). Pravda a metoda I. Nárys filosofické hermeneutiky. Praha: Triáda.

Giroux, H. A., \& McLaren, P. (1996). Teacher education and the politics of engagement: The case for democratic schooling. In P. Leistyna, A. Woodrum, \& S. A. Sherblom (Eds.), Breaking free: The transformative power of critical pedagogy (pp. 301-331). Cambridge, MA: Harvard Educational Review.

Habermas, J., \& Luhmann, N. (1971). Theorie der Gesellschaft oder Sozialtechnologie - Was leistet die Systemforschung? Frankfurt am Main: Suhrkamp Verlag.

Kasáčová, B., \& Kosová, B. (2007). Európske trendy a slovenský prístup k tvorbe učitel'ských kompetencií a spôsobilostí ako východisko k profesijným štandardom. Pedagogické rozhl'ady, 16(3), 1-6.

Kaščák, O., \& Pupala, B. (2007). Verachtung der Pädagogik und Verachtung in der Pädagogik - Erfahrungen hinter der östlichen Grenze. In N. Ricken (Ed.), Über die Verachtung der Pädagogik. Analysen - Materialien - Perspektiven (pp. 373-396). Wiesbaden: VS Verlag für Sozialwissenschaften.

Kaščák, O., \& Pupala, B. (2010). Neoliberálna guvernmentalita v sociálnom projektovaní vzdelávania. Sociologický časopis, 46(5), 771-799.

Kaščák, O., \& Pupala, B. (2011). Neoliberalizmus vo vzdelávaní: pät’ obrazov kritických analýz. Pedagogická orientace, 21(1), 5-34.

Kaščák, O., \& Pupala, B. (2012). Critical issues in contemporary education: Prolegomena. Human Affairs: Postdisciplinary Humanities \& Social Sciences Quarterly, 22(1), 3-10.

Korthagen, F. A. J., Kessels, J., Koster, B., Lagerwerf, B., \& Wubbels, T. (2001). Linking theory and practice: The pedagogy of realistic teacher education. Mahwah, NY: Lawrence Erlbaum Associates. Český překlad (2011). Jak spojit praxi s teorií: Didaktika realistického vzdělávaní učitelů. Brno: Paido.

Lautmann, R., \& Meuser, M. (1986). Verwendungen der Soziologie in Handlungswissenschaften am Beispiel von Pädagogik und Jurisprudenz. Kölner Zeitschrift für Soziologie und Sozialpsychologie, 38(4), 685-708.

Lenzen, D. (1996). Handlung und Reflexion. Vom pädagogischen Theoriedefizit zur Reflexiven Erziehungswissenschaft. Weinheim, Basel: Beltz Verlag. 
Lenzen, D. (1999). Orientierung Erziehungswissenschaft. Was sie kann, was sie will. Reinbek bei Hamburg: Rowohlt.

Liesner, A. (2006). Education or service? Remarks on teaching and learning in the entrepreneurial university. Educational Philosophy and Theory, 38(4), 483-495.

Lobkowicz, N. (1967). Theory and practice. Notre Dame, IND: Notre dame University Press.

Návrh na zmenu $v$ sústave študijných odborov $v$ skupine 1.1 výchova a vzdelávanie a na zmeny $v$ opise učitelských študijných odborov. (2012) Dostupné z http://radavs.sk/index. php?option=com_remository\&Itemid=21\&func=fileinfo\&id $=186$

Olssen, M., \& Peters, M. A. (2005). Neoliberalism, higher education and the knowledge economy: From free market to knowledge capitalism. Journal of Educational Policy, 20(3), 313-345.

Platón (1990). Dialógy. Bratislava: Tatran.

Pokus o teorii nepořádku - Rozhovor se Stephenem J. Ballem (2011). Studia Paedagogica, 16(2), 160-169.

Popkewitz, T. S. (1987). The formation of school subjects and the political context of schooling. In T. S. Popkwitz (Ed.), The formation of school subjets: The struggle for creating an American institution (pp. 1-24). New York: Falmer.

Prach, V. (1998). Řecko-český slovník. Praha: Vyšehrad.

Pritchard, R. (2005). Education staff and students under neoliberal pressure - a British-German comparison. Beiträge zur Hochschulforschung, 27(4), 6-29.

Pupala, B. (2010). Studia Paedagogica v českom časopiseckom prostredí: Komentár k monotematickému číslu 1/2009 Lidé ve škole a jejich vztahy. Pedagogická orientace, 20(2), 110-118.

Rieger-Ladich, M. (2007). Akzeptanzkrisen und Anerkennungsdefizite: Die Erziehungswissenschaft als subalterne Disziplin? In N. Ricken (Ed.), Über die Verachtung der Pädagogik. Analysen - Materialien - Perspektiven (pp. 159-184). Wiesbaden: VS Verlag für Sozialwissenschaften.

Sayler, W. M. (1968). Das Verhältnis von Theorie und Praxis in der Pädagogik. München, Basel: E. Reinhardt.

Schäfer, A. (2007). Das Problem der Grundlosigkeit als Provokation der Pädagogik. In N. Ricken (Ed.), Über die Verachtung der Pädagogik. Analysen - Materialien - Perspektiven (pp. 137-158). Wiesbaden: VS Verlag für Sozialwissenschaften.

Schön, D. (1983). The reflective practitioner: How professionals think in action. London: Temple Smith.

Tenorth, H. E. (1989). Deutsche Erziehungswissenschaft im frühen 20. Jahrhundert. Aspekte ihrer historisch-sozialen Konstitution. In P. Zedler \& E. König (Eds.), Rekonstruktionen pädagogischer Wissenschaftsgeschichte (pp. 117-140). Weinheim: Deutscher Studien Verlag.

Tenorth, H. E. (1996). Normalisierung und Sonderweg - Deutsche Erziehungswissenschaft in historischer Perspektive. In M. Borrelli \& J. Ruhloff (Eds.), Deutsche Gegenwartspädagogik, Bd. 2 (pp. 170-182). Hohengehren: Schneider Verlag.

Thiersch, H. (1978). Alltagshandeln und Sozialpädagogik. Neue Praxis, 8(1), 6-23.

Tschamler, H. (1996). Wissenschaftstheorie: Eine Einführung für Pädagogen. Bad Heilbrunn: Klinkhardt.

Webb, P. T. (2007). Accounting for teacher knowledge: Reterritorializations as a epistemic suicide. Discourse: Studies in the Cultural Politics of Education, 28(2), 279-295. 


\title{
Autori
}

Prof. PhDr. Emil Višňovský, CSc., Slovenská akadémia vied,

Ústav výskumu sociálnej komunikácie,

Dúbravská cesta 9, 81364 Bratislava; Univerzita Komenského v Bratislave,

Filozofická fakulta, Katedra filozofie a dejín filozofie, Gondova 2,

81499 Bratislava, e-mail: emil.visnovsky@savba.sk

Doc. PaedDr. Ondrej Kaščák, PhD., Prof. PhDr. Branislav Pupala, CSc.,

Slovenská akadémia vied, Ústav výskumu sociálnej komunikácie,

Centrum pedagogického výskumu, Dúbravská cesta 9, 81364 Bratislava;

Trnavská univerzita v Trnave, Pedagogická fakulta, Katedra predškolskej

a elementárnej pedagogiky, Priemyselná 4, 91843 Trnava,

e-mail: ondrej.kascak@savba.sk, branislav.pupala@savba.sk

\section{Pedagogical dualism of theory and practice: historic background and current illusions}

\begin{abstract}
The paper newly raises the traditional question of educational science - the question of the relationship between theoretical knowledge and practice, between science and practice. This target problem is discussed using a complex theoretical overview and integrating this problem of educational science into broader context of development of social sciences and humanities. Using this umbrella, transformations of relationship between theory and practice, discussed from the period of Classical Antiquity, through Modern period until present times, are interpreted. Consequently, transformations of relationship between theory and practice in this timeline provide a background for explaining the oscillation of self-representation of educational science as either theoretical or practical science. Finally, the well-known concept of teacher as reflective practitioner announced in the field of teacher training as a promising example of how to definitely bridge the gap between academic knowledge and knowledge necessary for practical execution of education is elaborated on.
\end{abstract}

Keywords: social sciences and humanities, educational science, theoretical and practical knowledge, fronesis, genesis of scientific discipline, reflective practitioner 